\title{
The Subjectivity of the Translator under the Influence of Two Cultures
}

\author{
Lai Kangsheng, Chen Jingming \\ Pingxiang University, Pingxiang, Jiangxi, 337055, China
}

\begin{abstract}
Keywords: Literary translation; the translator's subjectivity; cultural control
\end{abstract}
\begin{abstract}
According to Faucult's power discourse theory and Louis Althusser's ideology theory, any activities of the subjects are controlled by the power discourse and certain ideology. In the activity of translation, especially in the activity of literary translation, the subjectivity of the translator is also influenced and controlled by the two cultures of the source language and target language, in this situation, the subjectivity of the translator is embodied as the limited subjectivity of the translator in the tension between the two cultures. The language, as the means for the people to recognize and communicate with the outside world, also controls the freedom of the subjects and restricts their subjectivity. "In the modern time, the people have degraded the language from the transparent media to a distorted tool, from an antitype model to a limited existence." So, in the eyes of the postmodernists, the modern people have been trapped in the language, language constraints the man's subjectivity and the freedom of the man's recognition. Faulcult believes that the knowledge of arts and science can not exist, and the knowledge is fundamentally a form of power. So, in all, the translator, as the subject of discourse practice, and the media between two cultures, is inevitably influenced or controlled by the these two cultures which are showed or comprised of language, art, politics, religion, etc. of the peoples or the different countries.
\end{abstract}

\section{Introduction}

Based on Foucult's theory of power discourse and Louis Althusser's theory of ideology, we can say any subject is a kind of one that can't be free from the influence and restriction of some certain discourse power or ideology. The subjects are the people who live in the society, and whether their irrational or rational activities are unavoidably restricted. The subject as the translator is the media of two texts which represent or show two kinds of different cultures or ideologies, he is not only unable to disregard the existence of the source language and the source culture, but also unable to get himself free from the restriction from his own personality and target language and target culture in which he lives.

The history is the complex interrelationship of a variety of discourses, and how these discourses interact in any given historical period is controlled by the specific espisteme in that society, each era or people develop their own episteme, which is shaped by the specific interrelationship among the different discourses in that era or people, so we can say there is a different espisteme in different societies or for different peoples, and it is this espisteme that controls how a society or certain a group of people view the reality or the world around. Louis Althusser' theory of ideology emphasizes that the control and influence of the certain ideology in specific society on the thought, language and behavior of the people. By this theory, he means any man can't live beyond the influence from the ideology, and the ideology just refers to the people's general knowledge and view points of the religion, ethics, laws, politics, and aesthetics, and their general influence and control on the thought and behavior of the people's, so from this explanation, the ideology can be considered to be the same thing as the espiteme to some degree.

The language, as the means for the people to recognize and communicate with the outside world, also controls the freedom of the subjects and restricts their subjectivity. "In the modern time, the people have degraded the language from the transparent media to a distorted tool, from an antitype model to a limited existence." So, in the eyes of the postmodernists, the modern people have been trapped in the language, language constraints the man's subjectivity and the freedom of the man's recognition. Faulcult believes that the knowledge of arts and science can not exist, and the knowledge 
is fundamentally a form of power. So, in all, the translator, as the subject of discourse practice, and the media between two cultures, is inevitably influenced or controlled by the these two cultures which are showed or comprised of language, art, politics, religion, etc. of the peoples or the different countries.

\section{The Restriction on the Subjectivity of the Translator by the Culture and Ideology}

According to Faucult, "the power, discourse, and knowledge come into effect as a whole. Behind some certain discourses there always exists some certain power, and behind some certain power there always exists some certain knowledge that supports it. Some certain knowledge can justify some certain power, and the power can, in turn, systematize the knowledge, and make it hold the authoritative place.'[1] So in a society, the power and the knowledge is closely related to each other, and dependent on each other, they are a pair of commensals, with the power producing the knowledge and the knowledge legitimizing the power. Based on this theory of power discourse and knowledge, Faulcult puts forward the term of 'episteme', a unifying principle or pattern that determines the ways the people in a certain society think and talk about their world. Because, for faulcult, the history is the complex interrelationship of a variety of discourses, and how these discourses interact in any given historical period is controlled by the specific espisteme in that society, each era or people develop their own episteme, which is shaped by the specific interrelationship among the different discourses in that era or people, so we can say there is a different espisteme in different societies or for different peoples, and it is this espisteme that controls how a society or certain a group of people view the reality or the world around. Louis Althusser' theory of ideology emphasizes that the control and influence of the certain ideology in specific society on the thought, language and behavior of the people. By this theory, he means any man can't live beyond the influence from the ideology, and the ideology just refers to the people's general knowledge and view points of the religion, ethics, laws, politics, and aesthetics, and their general influence and control on the thought and behavior of the people's, so from this explanation, the ideology can be considered to be the same thing as the espiteme to some degree.

Like any other subjects, the translator is also a subject of discourse practice, and the subject of recognition who lives in certain society, so the translator's thought and translational behavior of discourse practice, like all other subjects, is also controlled by the 'epiteme' or ideology in that culture, just as what these words show , "It is the interaction among many different discourses which shapes a culture and interconnects all human activities, including the writing, reading, and interpretation of a text....". [2] Here, a typical case which shows the characteristics of the discourse is the language. The language, as the means for the people to recognize and communicate with the outside world, also controls the freedom of the subjects and restricts their subjectivity. "In the modern time, the people have degraded the language from the transparent media to a distorted tool, from an antitype model to a limited existence." [3] So, in the eyes of the postmodernists, the modern people have been trapped in the language, language constraints the man's subjectivity and the freedom of the man's recognition. Faulcult believes that the knowledge of arts and science can not exist, and the knowledge is fundamentally a form of power. So, in all, the translator, as the subject of discourse practice, and the media between two cultures, is inevitably influenced or controlled by the these two cultures which are showed or comprised of language, art, politics, religion, etc. of the peoples or the different countries.

\section{Translator' Subjectivity Influenced by the Two Cultures Embodied in the Translational practices of Literary Works}

\subsection{Translation as the way to reform the local society}

In the history of the translation, the influence of the different cultures on the translation action of the translator has never stopped. In the later Qing Dynasty and the early Ming in China, some translators as political activitists, often change the subjects, the structure, and the characters in the source texts, or willingly add or cancel the contents when translating the foreign literary works, in 
order to emphasize the political colors or the educational usage of the fictions. 《悲惨世界》translated by $\mathrm{Su}$ Manshu is one of that examples. In her translated work, there are fourteen chapters, among which, except the four chapters in the earliest part and the another four in the last part of the work which have only been changed partly from the source novel, the rest six chapters in the middle part are almost all her self-created contents. The target work doesn't accord to the source work, because there are too many places which have been randomly added or changed by the translator. In order to make use of the educational function of the novel, when translating the target work, Su Manshu criticizes Chinese fault ideology and the old and useless custom through the mouth of the foreigners, just as she translates: “那支那国的孔子的奴隶教训, 只有那班支那那践种奉为金科玉律; 难 道我们法兰西贵重的也得听他的那些狗屁吗? ” “那支那的风俗极其野蛮, 人人花费许多银 钱，焚化许多香纸，去崇拜那些泥塾木雕的菩萨。”[3]

Luxun's "Bringing-ism" also embodied his recognition of the Chinese culture and the nature of his people. This idea of translation just means the same as the cannibalism which is put forward by the Brazilian brothers Haroldo and Augusto de Campos, meaning that the translation is just like the activity of cannibals (who eat the white colonizers, in order to nourish themselves and make themselves become superior.), the translator digests the source text, and absorb its distillate, in order to culturally nourish himself well enough to create new target text. But here Luxiu put forward the "Bringing-ism", which is a kind of Foreignizing Translation, with the aim to opposite the feudalism and improve the nature of Chinese people.

\subsection{Translation as the way to resist the traditional idea of the west on the east and also as the way to subvert the western culture}

Any translation is under the influence and restriction of the two cultures at any time. And when the target language is not the local one but a foreign language, then the translation is influenced more by the target culture and the translator's recognition and his view on that culture and some idea of its. When translating 《论语》, Gu Hongming used the explanative and analogical ways of translation, in order to help the western people to understand the Confucian classics in China which makes the foundation for the wisdom and moral of Chinese people. In Gu's consciousness, he knew very clearly that the western people didn't know the value and the pith of Chinese culture, and they have a prejudice against the Chinese people. And as he told us in the preface of the translated work, the aim of this translation is that he wants to show his hope that the western people, after reading this translated work, can reflect their habitual prejudice against Chinese people, and as a result, they can remove this prejudice, and change their attitude on the relationship between two peoples and two countries. And when translating another Chinese classic 《中庸》, in the preface of the translated counterpart of this, he further points out that " if this small book that was the product of the wisdom of Chinese ancient people can help the European and American people to understand the 'Dao' better, and to form a comparatively clear and profound moral and responsible sense, discarding the European attitude of 'violent' and 'firearm' civilization, instead choosing the 'Dao', which means they follow the moral and responsible sense when communicating with Chinese people, whether personally or as a people, then he can think it has not waste his effort to try to understand and translate this classic. [4] When Gu translaing 《论语》, the title of it is "The Discourses and Sayings of Confucius, but the subtitle of it is " A Special Translation With Quotations from Goethe and Other Writers", so here he just wants to interpret the Confucian classics with the help of sayings written by some famous western writers. E.G. when translating “兴于诗”, he translate it into "In education sentiment is called out by the study of poetry.", but in the footnote, he quote Wordsworth's poetry further to interpret it like this, "Wordsworth says of poetry that it tends to: "Norish the imagination in her growth, and give the mind that apprehensive power, whereby she is made quick to recognize the moral properties and the scope of the things."

In the context of postcolonialism, the translation as a kind of political discourse practice of the postcolonialism is also a way to subvert the western culture. In the translational practice of postcolonialism, the translational technique of 'hybridity' is one of the translational techniques used 
to translate the target language into the European and American languages to subvert its culture. The theorists of the postcolonial translation believe that the translation, as the media of communication between different cultures, is the best way to remove or embody the hybridity of the cultures. So just as Christina Schaffner and Beberly Adab point out, that hybridity text is produced by the course of translation, this kind of text shows some characteristics that look alien to the target culture, but all of these characteristics are showed by the translator consciously, not as the result of his incompetence for translation. During the translation, especially the literary translation, the translator remain the hybrid contents and forms which are comprised of multiple cultures and firms by using the technique of Foreignizing Translation, as for a eastern colonized translator, they would remain the components that are typically eastern but are unidiomatic usage to the western readers when translating a literary work into the western world. By this way, the local culture and the heterogeneity of the languages are showed adequately, and the cultural hegemony of the Eurocentricism is deconstructed.

Based on Foucult's theory of power discourse and Louis Althusser's theory of ideology, we can say any subject is a kind of one that can't be free from the influence and restriction of some certain discourse power or ideology. The subjects are the people who live in the society, and whether their irrational or rational activities are unavoidably restricted. The subject as the translator is the media of two texts which represent or show two kinds of different cultures or ideologies, he is not only unable to disregard the existence of the source language and the source culture, but also unable to get himself free from the restriction from his own personality and target language and target culture in which he lives. And this study will help us to recognize the fact that the translation, as a power or ideology discourse practice according to Faulcult and Althusser, and as a bridge across which two cultures meet, have always played a great role in the communication of different cultures; and the fact that the subjectivity of the translator is a limited one which has been always influenced or restricted by different cultures and ideologies (including his own). All of this knowledge about the subjectivity of the translator will help the translator to set up a more rational communication between different cultures through his translational action, under the multicultural context of today.

\section{Summary}

The subjectivity of the translator is the main topic concerned by the translation theory and theorists of today. Especially when the economical globalization and cultural multiplication has been the main character of the new era, and when the cultural communication has become more and more often between different countries or peoples with the coming of the economical globalization, it will be more significant to study the characteristics of the subjectivity of the translator under the influence and restriction of the two cultures.

The language, as the means for the people to recognize and communicate with the outside world, also controls the freedom of the subjects and restricts their subjectivity. "In the modern time, the people have degraded the language from the transparent media to a distorted tool, from an antitype model to a limited existence." So, in the eyes of the postmodernists, the modern people have been trapped in the language, language constraints the man's subjectivity and the freedom of the man's recognition. Faulcult believes that the knowledge of arts and science can not exist, and the knowledge is fundamentally a form of power. So, in all, the translator, as the subject of discourse practice, and the media between two cultures, is inevitably influenced or controlled by the these two cultures which are showed or comprised of language, art, politics, religion, etc. of the peoples or the different countries.

\section{References}

[1] Bressler, Charles. E. Literary Criticism: an introduction to theory and practice[M]. Pearson Education, 2003.

[2] Mo Weimin. The fate of the main body [M]. Shanghai: Shanghai Sanlian Publishing House, 1996.

[3] Xu Jun, Zhang Baoran. Translation study for the twenty-first century [M]. Beijing: Commercial Press, 2002. 
[4] Xie Tianzhen. Translation of theoretical construction and cultural perspective [M]. Shanghai: Shanghai Foreign Language Education Press, 2000.

[5] Zhang Deming. Criticism of the vision [M]. Shanghai: Shanghai Academy of Social Sciences Press, 2004.

[6] Murdoch Iris, The Sublime and the Good in existentialism and Mystics[M]. New York: Penguin Books, 1997

[7] Murdoch Iris. Literature and Philosophy in existentialism and Mystics[M] New York: Penguin Books, 1997.

[8] Murdoch Iris. The Sovereignty of Good Over Other Concept in existentialism and Mystics[M] New York: Penguin Books , 1997.

[9] Murdoch Iris [M]. On God and Goodness in The Sovereignty, 1967

[10]Murdoch Iris, On God and Goodness in The Sovereignty, in existentialism and Mystics[M] New York: Penguin Books, 1997.

[11]Murdoch Iris, the Sovereignty of Good Over Other Concept in existentialism and Mystics[M] New York: Penguin Books, 1997. 